\title{
Structure and Function of Smooth Muscle with Special Reference to Mast Cells
}

\author{
Angel Vodenicharov
}

Additional information is available at the end of the chapter

http://dx.doi.org/10.5772/48566

\section{Introduction}

The structure of the smooth muscle tissue is quite different from that of other muscle tissue subtypes. The primary smooth muscle structural and functional unit - the smooth muscle myocyte (Myocytus nonstriatus) has unique structure, arrangement and innervation. The spindle shape of the mononucleated smooth muscle cell permits a close contact among cells in the splanchnic and vascular walls. Regardless of its location in the body, the communication between tightly packed adjacent spindle-shaped mononucleated smooth muscle cells occurs via a specific junction, referred to as Macula communicans (nexus, gap junction). The space between the different macular connexons is about $2 \mathrm{~nm}$, which allows low-molecular compounds to pass from one cell to another. This type of junction is analogous to the plasmodesma (pl. plasmodesmata), encountered in cells of plants. The basement membrane covering each smooth muscle cell, is absent at gap junction sites.

The contractility, proper of smooth muscle cells, is influenced by the autonomic nervous system, hormones and local metabolites, which alter the contractility in a way that adapts to the new functional requirements. Smooth muscle cell contraction could be modulated via surface receptors, activating internal second messenger systems. The expression of a variety of receptors accounts for the response of smooth muscle cells in different areas to a number of hormones [1].

It is known that for the major part of smooth musculature (except for the iris, vas deferens and large blood vessels) one autonomic nerve fibre innervates a group of 15-20 smooth muscle cells, as the stimulus to one cell is transmitted via nexus contacts to the other [2] assuming a simultaneous contraction of the pack of cells. This pathway of stimulus transmission naturally raises the question whether the excitation potential decreases towards more distant cells and whether the smooth muscle contraction and relaxation is mediated by biologically active substances, released by adjacent cells. In this connection, the 
proof of [3] that in vitro equine cecal smooth muscle contractions could occur without the nervous system participation is important to understand the biology of smooth muscle cells. Later, other researchers ([4] added new important data about the involvement of an unique, in their opinion, adhesion molecule of mast cells - the cell adhesion molecule-1 (CADM-1), which mediates the functional communication between mast cells and nerves, as well as between smooth muscle and mast cells. They outlined that in bronchial asthma, mast cells infiltrated the smooth muscles of airways and interacted directly with smooth muscle cells, presuming a role of mastocytes in the pathogenesis of airway obstruction.

The interaction between mast cells and vascular smooth muscle cells that are largely involved in vascular wall motility is of special interest for the cardiovascular system function. The presence of mast cells in blood vessels' wall and especially in the tunica media (the muscle layer), supposes a participation in smooth muscle cell activity modulation via release of vasoactive mediators. A similar effect could be hypothesized when mast cells are located close to the blood vessels from the microcirculatory bed and to arterioles in particular, as it is recognized that arterial blood pressure is largely influenced by the smooth muscle tone in the wall of arterioles.

Besides the classic and more recent data about biologically active substances released by mast cells, and implicated in smooth muscle cell activity, this chapter presents concisely some original information about the localization of mast cells in muscle layers of blood vessels and visceral organs. On the basis of this information, the role of known mast cell mediators modulating smooth muscle cells' activity in studied organs and tissues is discussed.

\section{Brief characteristics of the mast cell and its role for smooth muscle}

The mast cell (Mastocytus) or tissue basophilic granulocyte (Granulocytus basophilus textus) was observed for the first time about 150 years ago and since then, is described as a connective tissue cell. Mastocytes are usually present in loose connective tissue of organs, communicating with the environment - digestive and respiratory organs, skin.

It is acknowledged that the structure and the function of mast cells are similar to those of blood basophils, but the two cell types have different precursors [5]. The main biological function of mast cells is the release of inflammatory mediators and cytokines [6]. They are outlined as cells with paracrine secretion (messenger-producing cells), whose products disseminate in the extracellular fluid and act on adjacent target cells [7]. Furthermore, mast cells are rich in histamine, heparin and proteases. Histamine is a vasoconstrictor increasing the permeability of small venules and stimulator of small-airway smooth muscle contraction. Heparin acts as an anticoagulant and is thought to stimulate angiogenesis [8]. Heparin proteoglycan, released by activated mast cells, inhibits the proliferation of smooth muscle cells in arterial tunica media and uterine myometrium $[9,10]$.

The accumulated evidence on biologically active substances, synthesized, stored and released by mast cells over the last 2-3 decades not only added to the information about 
their heterogeneity and biology, but also gives reason to re-evaluate their participation in important processes as the homeostasis, immune response, allergy, neurotransmission, vasomotor activity and motility of smooth muscle tissue. With regard to the blood flow to organs and blood circulation, the research on vasoactive substance released by mast cells and playing a key role in the vascular motorics, is particularly important. This role is primarily related to blood flow regulation in various functional states - both physiological and pathological. The tentative role of mast cells in the modulation of splanchnic wall smooth muscle tissue, accomplished by specific mediators, is comparable.

Despite the abundant literature data related to the morphology, localization, histochemical behaviour, species-related features and involvement in systemic homeostasis, immune response, allergy, anaphylaxis etc. of tissue basophil granulocytes (mastocytes), the information about their presence in smooth muscle tissue is still scarce.

Among the nearly 70 biologically active substances found in mast cells so far, it could be affirmed that mast cell-derived ligands, which act as mediators of smooth muscle tissue motility, belongs to four groups, namely:

Biogenic amines (incl. catecholamines): histamine, dopamine, serotonin

Polypeptides (including neuropeptides): vasoactive intestinal polypeptide (VIP), endothelin

Proteoglycans: heparin

Free radicals: nitric oxide

The content and expression of mentioned biologically active substances outline mastocytes as cells, involved in the functioning of the smooth muscles of internal organs and blood vessels.

In our studies, histochemical and immunohistochemical methods were used on paraffin sections, cryostat, semi-thin and ultrathin sections.

\section{Considering selected substances}

\subsection{Biogenic amines}

There are literature reports about mast cells containing biogenic amines, established by the method of [11] via alcian blue/safranin staining with relatively low $\mathrm{pH}$ of the staining solution (1.42). Such cells were identified in bovine trachea [12,13], as well as in several porcine organs [14]. In porcine renal blood vessels, renal pelvis and ureter, the specific staining for biogenic amines and glycosaminoglycans allowed to determine the localization and counts of alcian-positive mast cells in the tunica media, on its boundary with the adventitia and less frequently on its boundary with the intima Fig. 1. It should be noted that alcian-positive mast cells in renal pelvis and ureter were preferentially located in the muscle layer compared to the other layers of the wall, with statistically significant differences $[15,16]$. 


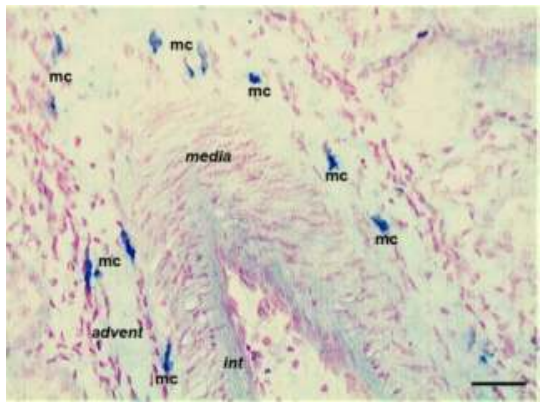

Figure 1. Longitudinal section from a part of the wall of the porcine kidney interlobar artery. int - intima; media - middle shell; advent - adventitia. The $\mathrm{A}^{+}$mast cells $(\mathbf{m c})$ are located mainly between the media and adventitia. Alcian blue - safranin. Bar $=50 \mu \mathrm{m}$.

The observed findings were confirmed by electron microscopy as well Fig. 2. No direct contact, neither specialized contact differentiations between mast cell and smooth muscle cell plasmalemmas, were noted in any case.

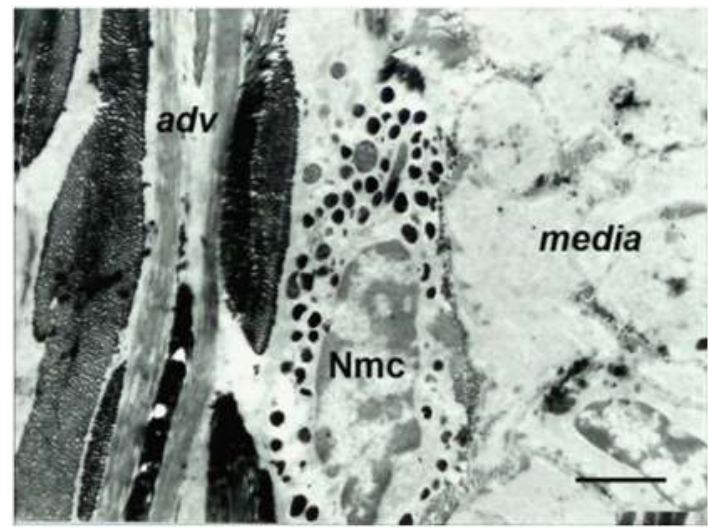

Figure 2. Mast cell (Nmc), located between middle shell (media) and adventitia $(\mathbf{a d v})$ of porcine renal interlobar artery. TEM picture. $\mathrm{Bar}=5 \mu \mathrm{m}$.

\subsubsection{Histamine}

Histamine is a biogenic (vasoactive) amine, mediator of inflammation, gastric hydrochloric acid secretion and smooth muscle contraction [17]. Histamine is detected in mast cells, nerve and neuroendocrine cells, lungs, kidneys, cerebrovascular endothelial cells, peripheral nervous system [18]. It elicits a contractile response in smooth muscles and lowers blood pressure [19].

Histamine is released by mast cells in response to allergic reactions or tissue damage. The close vicinity of mast cells to blood vessels, together with the strong vascular effect of histamine suggests that it could influence blood flow, including that of the brain [20]. Histamine acts upon visceral (smooth) musculature by contracting it [8]. 
Histamine has a marked cardiovascular effect as well. It provokes dilation of terminal arterioles and the other vessels from the microcirculatory vascular bed, increases the permeability of capillaries during oedema formation and causes contraction of smooth muscle cells of large arteries and veins. The relative predominance of these effects is species-dependent. For instance, the histamine-induced contraction of arterioles is strong in rodents, less pronounced in cats, while they are dilated in dogs, non-human primates, and humans [19]. It was initially thought that vascular effects of histamine were mediated only by $\mathrm{H}_{1}$ receptors. Later data confirmed the presence of $\mathrm{H}_{2}$ receptors. Histamine-induced changes in the permeability of small vessels were obviously mediated by $\mathrm{H}_{1}$ receptors, whereas the role of $\mathrm{H}_{2}$ receptors in small arteriole contractions is still uncertain. The exact ratio of $\mathrm{H}_{1}$ - and $\mathrm{H}_{2}$ - receptor involvements in vascular responses to histamine in the different animal species is variable [21].

In general, the effect of histamine on a specific regional vasculature could be best described as a result of its multiple effects on smooth muscle and the lining endothelium. $\mathrm{H}_{1}$ and $\mathrm{H}_{2}$ receptors on vascular smooth muscle mediate direct constriction and relaxation, respectively, while endothelial $\mathrm{H}_{1}$ receptors promote vasorelaxation via release of endothelial-derived relaxing factor (EDRF: i.e. nitric oxide) and/or prostacyclin. It is supposed that the transmembrane signalling mechanisms are involved in the different effects of histamine on vascular smooth muscles [22, 23].

The role of histamine as a chemical mediator of renal autoregulation in some animal species is long acknowledged. $\mathrm{H}_{1}$ receptors mediate the autoregulation of both renal blood flow and glomerular filtration rate in dogs, whereas in rabbits, both effects are present - $\mathrm{H}_{1}$-mediated contraction and $\mathrm{H}_{2}$-mediated relaxation of the renal artery [24-26].

Immunohistochemically, histamine-positive mast cells were found in all layers of renal blood vessels in pigs [16]. They were most numerous in the tunica media, as well as at the boundary between media and adventitia (Fig. 3). In the tunica media of arcuate arteries, histamine-positive mastocytes were relatively few, while in arcuate veins were observed only as single findings.

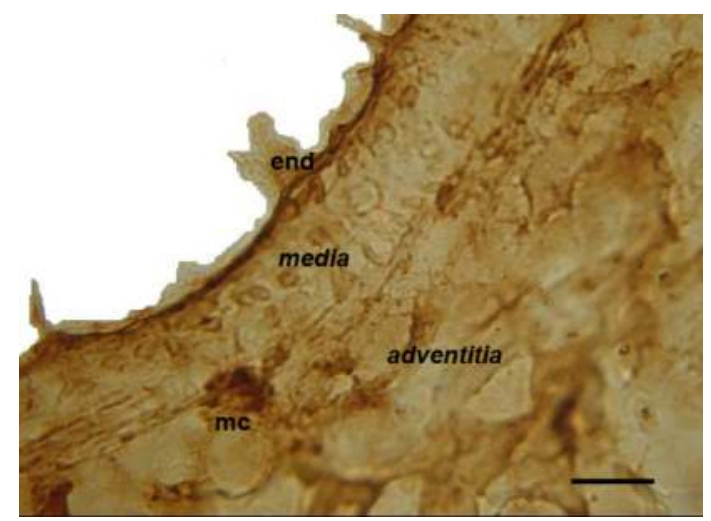

Figure 3. Histamine positive mast cell (mc) between media and adventitia of porcine interlobar artery. Bar $=30 \mu \mathrm{m}$ 
Histamine-positive mast cells were also detected in the middle layer of the renal pelvis and the ureter of the pig [15, 16], (Fig. 4).

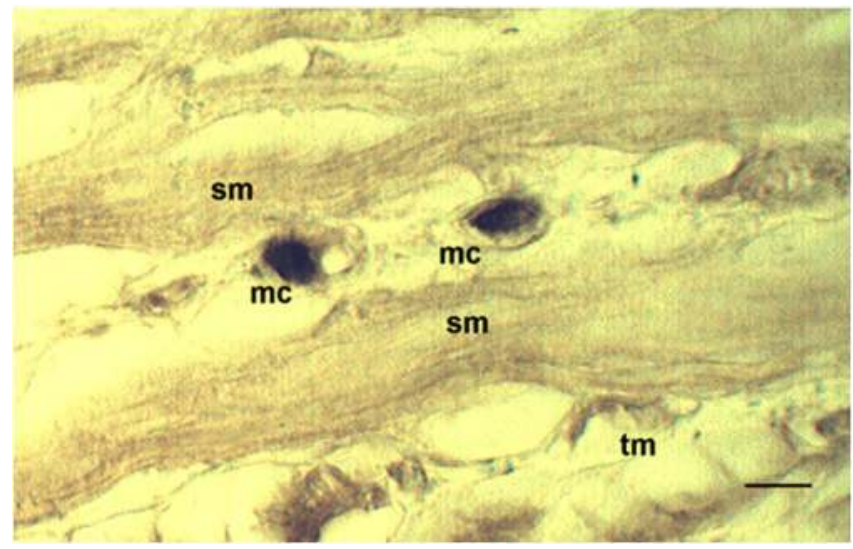

Figure 4. Two histamine positive mast cells $(\mathbf{m c})$ in the circular smoothlayer $(\mathbf{s m})$ of porcine ureter. tm - mucosal sheet. Bar $=25 \mu \mathrm{m}$

\subsubsection{Dopamine}

Dopamine belongs to the group of catecholamines, which are direct-acting sympathomimetic amines. Adrenergic nerves are not required for their effects because they activate the receptors of effector cells. This is mainly valid for already synthesized and exogenous catecholamines [27]. Before, dopamine was believed to be important only as an immediate precursor of norepinephrine (noradrenalin, levarterenol, arterenol), but later some of its important physiological functions in mammals were revealed and thus, it was considered more thoroughly in some clinical states in men [28]. Apart from its significance for nervous system, dopamine is tightly related in cardiovascular activity. Cardiovascular effects of dopamine depend on the activation of different types of catecholamine receptors. Its pressor effect is inhibited by an $\alpha$ blocker (such as phenoxybenzamine). Cardiac stimulating effects however, could be inhibited by a $\beta$ blocker (for example, propranolol) [29].

Dopaminergic receptors of vascular beds could be considered a fifth adrenergic receptor subtype. Although the physiological significance of dopamine receptors is unknown, this type is important for clinical pharmacology as it is involved in vasodilator responses in renal, coronary and brain circulatory beds. The activation of these receptors by dopamine is highly selective, while the agonistic activity of other catecholamines is minor [27].

By opinion of [29] dopamine induced a reduction of vascular resistance and increases the blood flow to kidneys and mesenteries blood vessels, together with myocardial stimulation. This partial effect of dopamine could be advantageous in the treatment of shock compared 
to conventional catecholamines, because norepinephrine and epinephrine induce a marked contraction of renal and mesenterial arteries secondary to $\alpha$-receptor effects.

The selective vasodilation of renal and visceral beds by dopamine suggested its use in clinical cardiac dysfunctions. It is successfully used in treatment of shock as it dilates renal arteries through activation of dopamine-1 ( $\left.\mathrm{DA}_{1}\right)$ receptors and enhances cardiac activity via activation of cardiac $\beta$-adrenergic receptors [20, 27]. Dopamine receptors on vascular smooth muscles are classified by $[30,31]$ as DA1.

With regard to the presence of dopamine in mast cells, data available so far describe it as mastocyte amine mediator only in ruminants [32].

Using a histochemical reaction for the detection of tyrosine hydroxylase $(\mathrm{TH})$ - a primary enzyme in dopamine synthesis pathway in porcine kidney, it was found out that THpositive mast cells were predominantly localized at two sites: the renal sinus and in glomeruli of the superficial, middle and juxtamedullary cortical zones [16]. TH-positive mast cells in the renal sinus were usually seen as single cells, less frequently as clusters of several cells near the large blood vessels (Fig. 5).

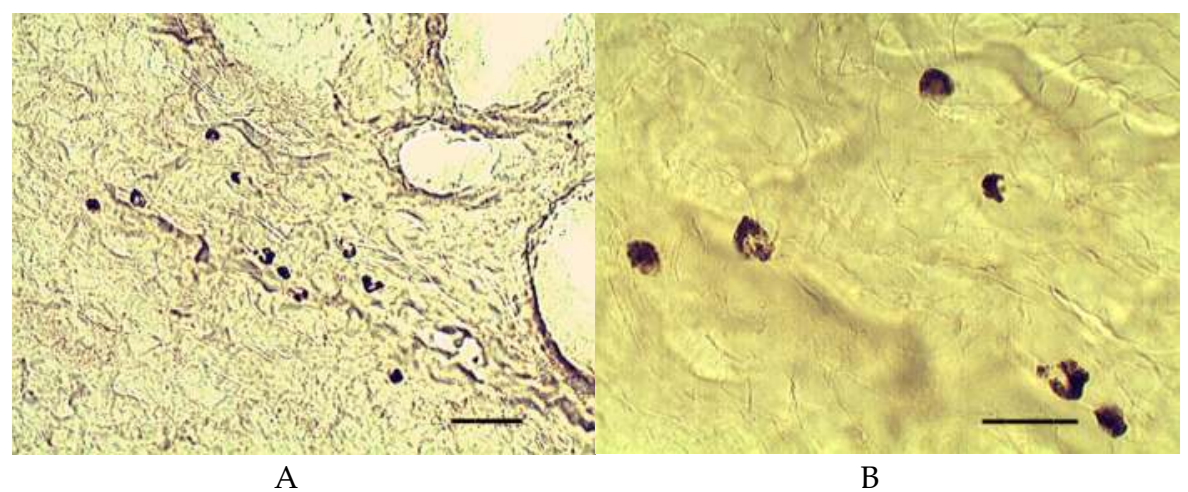

Figure 5. A. TH-positive mast cells in the renal sinus, gathered near the blood vessels. Bar $=100 \mu \mathrm{m}$ B. Some of TH-positive mast cells (upper half of $5 \mathrm{~A}$ at a higher magnification). Bar $=40 \mu \mathrm{m}$

TH-positive mast cells were not detected in the cortex. In our view, the absence of THpositive mast cells around and within cortical vessels is probably one of the reasons for the application of dopamine in spasms of the interlobular arteries to relieve anuria due to a variety of causes. Nevertheless, as outlined by [33], the application of dopamine in humans and some animal species with renal failure did not provoke the anticipated effect.

\subsection{Polypeptides}

\subsubsection{Vasoactive intestinal polypeptide (VIP)}

The vasoactive intestinal polypeptide is a multifunctional peptide built of 29 amino acids, first isolated from porcine duodenum [34] and initially considered a potential vasodilator. 
The extensive research on VIP in late 1980's revealed that this peptide is a physiological regulator of essential body functions, namely brain metabolism and blood flow, gastrointestinal motility and secretion, neuroendocrine secretion, immune response, sexual activity and reproduction. Along its importance in carcinogenesis, VIP is also related to diseases such as bronchial asthma, urinary bladder fibrosis and AIDS [35].

VIP was first described in mastocytes of rats and mice by [36], and its relationship to histamine was shown. Later, VIP was described in basophils as well [37]. As mast cells are abundant in the connective tissue of different organs, the contained VIP could influence the local or regional blood flow in both normal and pathological states [36].

It is acknowledged that VIP, some peptides and histamine secreted by mast cells are actively involved in the motility of smooth muscle (including vascular) cells and modulate the motility of smooth muscles in organs and the vascular wall through specific receptors [38-44].

Mast cells, immunopositive to VIP were observed in large blood vessels, including arcuate arteries and veins of pigs [16]. Relatively high mast cells counts were established within the media of these vessels, with highest density in the renal artery. Less VIP-positive cells were observed on the boundary between the media and the adventitia. It should be emphasized that in arcuate arteries, VIP-positive mast cells were present only in the middle shell, with relatively regular distribution along the circumference of the blood vessel (Fig. 6).

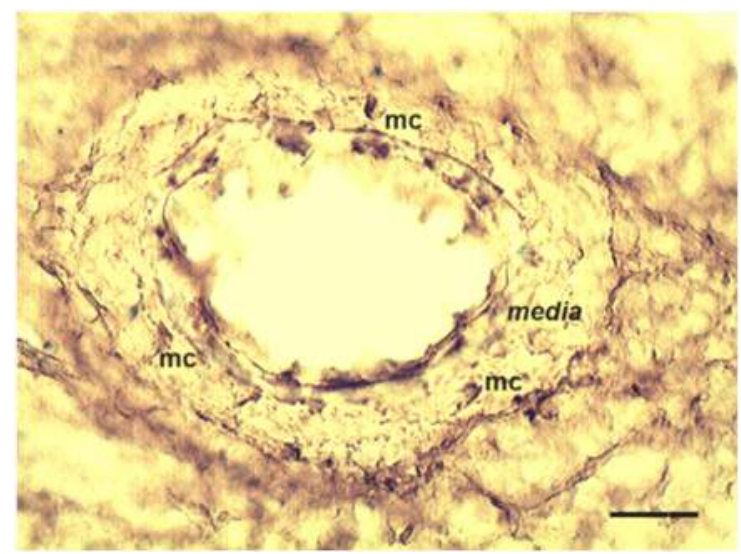

Figure 6. VIP positive mast cells (mc) in the middle shell (media) of porcine arcuate artery. Bar $=80 \mu \mathrm{m}$

\subsubsection{Endothelin}

Endothelin (ET) is a brain-vascular peptide [45], with three isopeptides - ET-1, ET-2 and ET3 [46]. Its various biological actions include, apart from the regulation of vasoconstriction and neurotransmission, the regulation of cytokine-regulated cell growth [47]. Out of the three ET isopeptides, ET-1 has marked effect mainly on smooth muscle cells of the vascular wall. 
ET-1 is a 21-amino acid peptide with a strong vasoconstrictor activity, first isolated from the supernatant of cultured endothelial cells. There is evidence that vascular smooth muscle cells are also capable to produce endothelin [48, 49]. Apart being a potent vasoconstrictor, ET-1 also exhibits hypertrophic, mitogenic and anti-apoptotic effects on vascular smooth muscle cells [50-52]. ET-1 induces strong and prolonged contractile responses in vascular smooth muscle cells in different systems, with a special effect on the renal vascular bed [48, 53-56]. Initially described as a vasoconstrictor, ET-1 is now acknowledged to participate in the pathogenesis of a number of disorders, i.e. vascular, inflammatory, fibrotic diseases via its multifunctional effects on mast cells, but under certain conditions [57].

ET-1 is widely spread in various tissues and organs, including the gastrointestinal tract. Its three isopeptides were detected mainly in mast cells and less frequently, in macrophages of Lamina propria of the stomach, small intestine and colon in Wistar rats. Apart the confirmed synthesis and secretion of ET by mast cells, its role as a new cytokine factor in these cells was suggested [46].

ET was reported to be present in the basilar artery of the rat $[58,59]$ and post mortem, in human cerebrovascular nerves of the middle cerebral artery [60]. Immunoreactive ET-1 was also detected in endothelial cells of the intima, vascular smooth muscle cells and macrophages of the media and neointima, and in perivascular nerves (axons) varicosities at the boundary between media and adventitia of the middle cerebral artery in a patient with multiple system atrophy with autonomic deficiency [61]. ET-1 positivity of uterine smooth muscle cells and mast cells was reported in a post partum mouse, but its functions remained unclear [62]. More recent data [3] from in vitro investigations showed the contractile effect of ET-1 on longitudinal smooth muscle of the equine cecum, mediated by ETA and ETв receptors. It was therefore concluded that the spontaneous contraction of equine caecal smooth musculature most probably originated in smooth muscle cells, and not in enteric nervous system. Having investigated the vasoconstrictor effect of ET-1 on resistant renal blood vessels in a rabbit through in vitro microperfusion of afferent and efferent glomerular arterioles, [63] established a dose-dependent decrease in their lumen.

Endothelin-immunopositive mast cells were present in the wall of both extrarenal and intrarenal blood vessels of the pig [16]. The largest amount of mast cells was observed in peripheral layers of tunica media, as well as on the boundary between media and adventitia. Endothelin-positive mastocytes were also observed in deeper layers of the media, in the connective tissue among smooth muscle cells. The detected mast cells were of different shape and with well visualized immunopositive granules. ET-positive mast cells in the wall of the renal vein were more rarely observed. Their localisation was similar to that in the renal artery. ET-positive mast cells were detected occasionally in the wall of intrarenal blood vessels, but only as single findings in arcuate and interlobular arteries and veins.

The research of [64] on mast cells in the wall of canine sublobular hepatic veins by transmission electron microscopy has shown that ET-1 was present in both the cytoplasmic matrix and cytoplasmic granules. According to the author, the coexistence of ET-1 and histamine in mast cell granules was closely related to the strong vasoconstrictor effect on venous sphincters of canine liver. 


\subsection{Proteoglycans}

\subsubsection{Heparin}

The strong correlation between the density of mast cells in tissues and the efficacy of tissue extracts to prevent blood coagulation, it was supposed long ago that mast cells contained the potent anticoagulant heparin. According to [65] heparin is the only large glycosaminoglycan and its amount in the cell is about $20 \mathrm{pg}$.

Activated mast cells, releasing heparin proteoglycans, inhibit the proliferation of smooth muscle cells in the tunica media of human arterial wall, while histamine stimulates it [10]. It was demonstrated by [9] the inhibitory effect of heparin on human myometrium proliferation, suggesting that it could induce the differentiation of uterine smooth muscle cells and to influence tissue remodelling and reconstruction in different physiological and pathophysiological events.

Glycosaminoglycan-positive, including heparin-positive mast cells were observed by us [16] in the walls of extra and intrarenal blood vessels in pigs (Fig. 7). To determine the amount of heparin-containing mast cells, they were initially stained with $0.02 \mathrm{w} / \mathrm{v}$ aqueous berberine neutral sulfate solution and then, with $0.1 \%$ toluidine blue in Mcllvane's buffer, $\mathrm{pH} 3$ and observed by light microscopy. Calculating the ratio of berberine-positive (heparin) to toluidine positive (glycosaminoglycans) with well expressed $\gamma$-metachromasia mast cells, it was found out that $42 \%$ of mast cells in the renal vein media were berberine-positive, i.e. contained heparin in their granules.

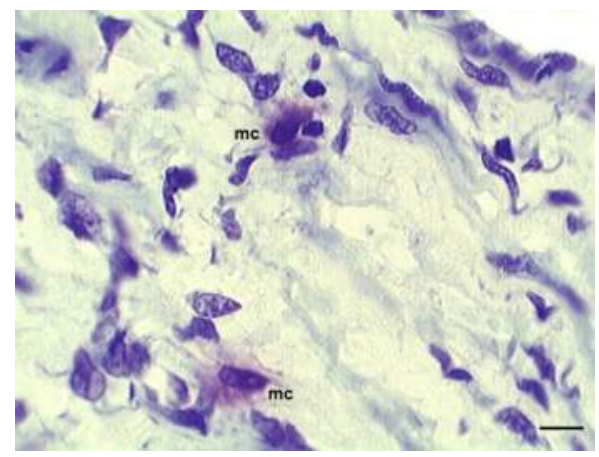

Figure 7. Mast cells (mc) in the media of porcine renal vein with well expressed $\gamma$-metachromasia. Bar $=30 \mu \mathrm{m}$

Similar studies with mast cells localized in the internal anal sphincter part, adjacent to the paranal sinus wall in the dog, showed that $100 \%$ of the mast cells were berberine (heparin) positive [66]. Positive reaction was detected both in mast cells in the connective tissue stroma among smooth muscle cell clusters, as well as within packs, in close vicinity to smooth muscle cells (Fig. 8). These data, compared to previously cited repots allowed assuming that heparin-containing mast cells regulated the growth of smooth muscle cells not only in the vascular wall, but also in the external anal sphincter in dogs $[16,66]$. 


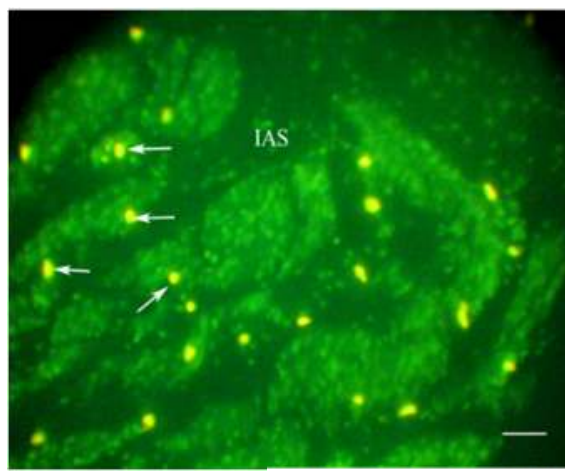

A

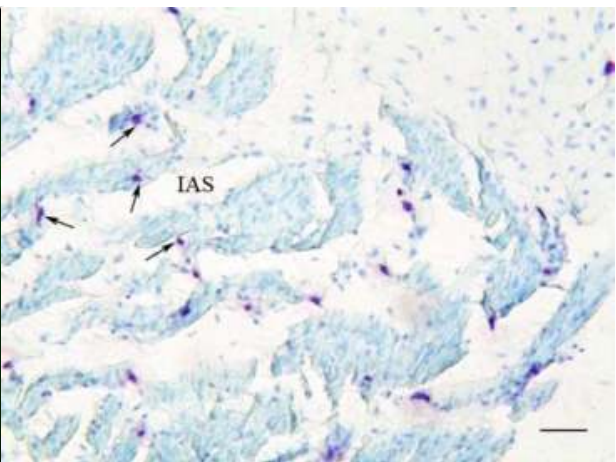

B

Figure 8. A. Heparin contained- berberin positive mast cells (arrows). IAS- internal anal sphincter. GA- apocrine glands. Male 4 years dog. Bar $=40 \mu \mathrm{m}$. (Courtesy by Dr I. Stefanov).

B. Toluidine blue staining of the same area - 8A. Mast cells with $\gamma$-ma metachromasia-glycosaminoglycans (arrows). Bar $=40 \mu \mathrm{m}$. (Courtesy by Dr I. Stefanov).

\subsection{Radicals}

\subsubsection{Nitric oxide}

Nitric oxide (NO) is a molecular free-radical gas, an important mediator with a variety of functions [67]. $\mathrm{NO}$ is biosynthesized from the guanidine nitrogen $\left(\mathrm{N}^{\mathrm{G}}\right)$ of L-arginine through conversion of the intermediate compound $\mathrm{N}^{\omega}$-hydroxy L-arginine by nitric oxide synthase (NOS) enzyme family. As this family of enzymes incorporates molecular oxygen, NOS are classified as dioxygenases with similar features with cytochrome P-450 reductase. Cofactors needed for NO synthesis include flavin adenine dinucleotide (FAD), flavin mononucleotide, nicotinamide adenine dinucleotide phosphate (NADPH), haemoglobin and tetrahydrobiopterin.

Three NOS isoforms are known- NOS 1 (neuronal, nNOS), NOS 2 (inducible, iNOS) and NOS 3 (endothelial, eNOS). NOS 1 and NOS 3 (nNOS and eNOS) are also described as constitutive NOS (cNOS), the other original form is iNOS. NOS-coding genes are localised in different chromosomes. The structure of enzymes is common, i.e. oxygenase, reductase domain and calmodulin-binding site, with 51 to 57\% homology in amino acid sequences. The C-terminal reductase domain possesses binding sites for FMN-, FAD- and NADPH, and is linked to the oxygenase domain by a calmodulin-binding site [68, 69].

Apart regulating the mast cell phenotype and function [70], $\mathrm{NO}$ is also produced by mast cells. There are numerous data confirming the production of this important signalling molecule by mast cells [71], but also data opposing to this statement [72].

There is increasing evidence in support of the fact that the release of mediators by mast cells is regulated by NO, most probably through posttranslational modification of proteins. The three isoforms of NOS are expressed in mast cells, although other cells also produce NO that 
could regulate mast cells' function. Probably, each of NOS isoforms in mast cells coordinates a specific outcome depending on the mast cell phenotype, subcellular distribution of the enzyme and the presence of various cofactors [72].

By [68] it was demonstrated that NO generated via eNOS is the main vasodilator responsible for hypotension in anaphylactic shock. The authors believe that soluble guanylate cyclase is the main vasorelaxing mediator of NO. These data support the surprising hypothesis that not iNOS but eNOS was the principal factor of vascular dilation in a state of anaphylaxis. Thus, eNOS and/or PI3K and Akt are defined as novel possible targets in anaphylaxis treatment.

Our studies on renal blood vessels in pigs showed that there were no mast cells, positive for NADPH-d and NOS [16]. Mastocytes positive to these ligands were detected in the internal anal sphincter of the dog [66]. In sexually mature animals, NADPH-d-positive mast cells were statistically significantly more numerous per $0.1 \mathrm{~mm}^{2}$ than NOS-positive cells $3.27 \pm 0.78$, vs. $1.65 \pm 0.62(\mathrm{p}<0.001)$.

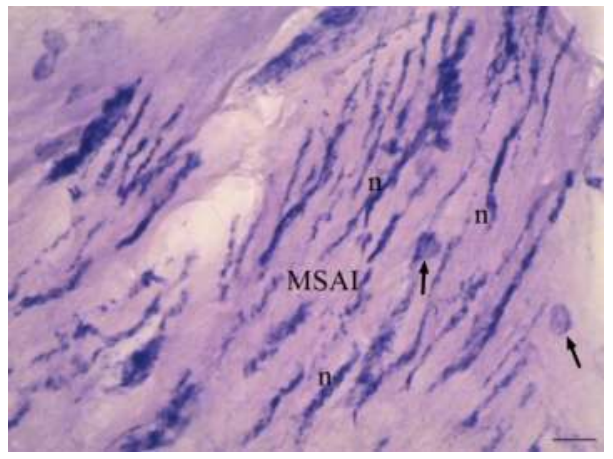

Figure 9. NADPH-d positive mast cells (arrows) and nerves (n) in dog's internal anal sphincter (MSAI). Bar $=15 \mu \mathrm{m}$. (Courtesy by Dr I. Stefanov)

\section{Some morphofunctional aspects of the interaction between smooth muscle cells and mast cells}

The presence of mast cells containing biogenic amines and other mediators, the histochemical evidence for aforementioned ligands and more recent literature data suggesting that the nervous system is perhaps not the only mediator of smooth muscle contractility [3], allowed to hypothesize that mast cells were actively involved in smooth muscle cells motility. In support of this assumption, a detailed study of mast cells in the ureteral wall was conducted [15]. The results convincingly demonstrated that their role was substantial and incontestable. The highest mast cell density per $\mathrm{mm}^{2}$ in the muscular layer of the ureter $(16.7 \pm 3.3)$ compared to mucosa and adventitia (7.3 \pm 1.8 and $11.1 \pm 2.7$, respectively) was probably related to the marked activity of closely situated smooth muscle cells. This assumption is based upon the opinion of [13] about bovine tracheal mast cells. Ureteral smooth musculature 
activity is manifested, in the first place, by periodic contractions sending urine into the urinary bladder (due to the horizontal position of the animal) and second, by blood flow regulation through vasoconstriction control [73] and/or modulation of smooth muscle activity $[38,41,43]$. This primary activity of mast cells in the porcine ureter is different to that in other organs such as lungs, alimentary organs and the skin, where mast cells are involved in immune response to external antigens, easily invading the body in large amounts [6]. This could be attributed to the specific retroperitoneal localisation of the ureter [74], which is relatively unexposed to such antigens.

It is well acknowledged that autonomic nerve fibres did not connect each smooth muscle cell in a large part of organs and blood vessels [2, 75]. Therefore, signals could be transmitted by nexus ion channel contact between mast cells and muscle cells - most probably via substances like $\mathrm{Ca}^{2+}, \mathrm{Mn}^{2+}[76], \mathrm{K}^{+}[77], \mathrm{Cl}^{-}[78,79]$, enzymes [73], biologically active substances as the vasoactive intestinal polypeptide - VIP [36, 37], histamine [13, 73, 80], and substance P [81], all of them responsible for signal transduction.

The detailed elucidation of mast cells effects on smooth muscle cells requires special attention on the tentative role of mastocytes in myometrium recovery [82], emergence of smooth muscle contraction [3], and the specificity of autonomic innervation of smooth muscle tissue $[1,75]$.

\section{Conlusion}

The presented data convincingly show that mast cells are normally resident cells in the smooth muscle layer of the blood vessels and the visceral organs. Established biologic active substances in observed mast cells with emphasized importance for smooth muscle motility give a reason to believe that mast cells via these substances take part in modulation of smooth muscle cells activity. This presumption could be useful for further investigations, which apparently will allow more detailed elucidation on mast cells function in smooth muscle tissue, as whole.

\section{Author details}

Angel Vodenicharov

Department of Veterinary Anatomy, Histology and Embryology, Faculty of Veterinary Medicine, Trakia University, Stara Zagora, Bulgaria

\section{References}

[1] Young B, Lowe J. S, Stevens A, Heath J. W (2006). Basic tissue types. In: Wheather's Functional Histology, A Text and Colour Atlas, $5^{\text {th }}$ ed, Churchill Livingstone Elsevier, pp. 78-79.

[2] Chouchkov Ch (1995) Smooth muscle tissue. In: Koichev K, editor. Koichev Anatomy of the Man. Sofia: Meditzina and Fizkultura Publishing House, part I, pp.103-104. 
[3] Chidambaram R, Eades S, Moore R, Hosgood G, Venugopal Ch (2005) Characterization of the in vitro responses of equine cecal longitudinal smooth muscle to endothelin-1. American Journal of Veterinary Research 66: 1202-1208.

[4] Ito A, Hagiyama M, Oonuma J (2008) Nerve-mast cell and smooth muscle-mast cell interaction mediated by cell adhesion molecule-1, CADM1. Journal of Smooth Muscle Research. 44: 83-93.

[5] Shiohara M, Koike K (2005) Regulation of mast cell development. Chemistry Immunology Allegry. 87: 1-21.

[6] Hill P.B, Martin, R. J (1998) A review of mast cell biology. Veterinary Dermatology. 9: 145-166.

[7] Junqueira L. C, Carneiro J, Kelly R. O (1992) Basic Histology. $7^{\text {th }}$ ed., East Nowalk, Connecticut: Appletion \& Lange. pp. 82, 111-113.

[8] Eurell J. C, Van Sickle D. C (1998) Connective and Supportive Tissues. Resident Cells of Connective Tissue. Mast cells. In:. Dellmann H. D, Aurell J. C, editors. Textbook of Veterinary Histology, $V^{\text {th }}$ ed., Baltimore, USA: Lippincott Williams \& Wilkins. p.35.

[9] Horiuchi, A, Nikaido T, Ya-Li Z, Ito K, Orii A, Fujii S (1999). Heparin inhibits proliferation of myometrial and leiomyomal smooth muscle cells through the induction of $\alpha$ smooth muscle actin, calponin h1 and p27. Molecular Human Reproduction. 5: 139-145.

[10] Wang Y, Kovanen P.T (1999). Heparin proteoglycans released from rat serosal mast cells inhibit proloferation of rat aortic smooth muscle cells in culture. Circulation Research. 84: 74-83.

[11] Csaba G (1990) Alcian blue - Safranin method for mast cells. In: Bancroft J. D, Steven A. editors. Theory and Practice of Histological Techniques. New York: Livingstone, p. 639.

[12] Hunt T, Campbell A, Robinson C, Holgate S (1991) Structural and secretory characteristics of bovine lung and skin mast cells: Evidence for the existence of heterogeneity. Clinical and Experimental Allergy. 21: 173-182.

[13] Harris W, Marshall J, Yamashiro S, Shaikh N (1999) Mast cells in bovine trachea: Staining characteristics, dispersion techniques and response to secretagogues. Canadian Journal of Veterinary Research, 63: 5-12.

[14] Xu R, Carr M, Bland A, Hall A (1993) Histochemistry and morphology of porcine mast cells. Histochemical Journal. 25: 516-522.

[15] Vodenicharov A, Leiser R, Gulubova M, Vlaykova (2005) Morphological and immunocytochemical investigations on mast cells in porcine ureter. Anatomia Histologia Embriologia. 34: 343-349.

[16] Vodenicharov A (2008) Morphological investigations on the role of mast cells mediators, other vasoactive substances and the glomerular arterioles in the renal hemodynamics of domestic swine. Doctor Vet. Med. Science Dissertation, Faculty of Veterinary Medicine, Trakia University, Stara Zagora, pp. 77-197.

[17] Schwartz L. B (1994) Mast cells: function and contents. Current opinion in Immunology. 6: 91-97.

[18] Panula P, Airaksinen M. S, Pirvola U, Kotilainen E (1990) A histamine-containing neuronal system in human brain. Neuroscience. 28: 585-610. 
[19] Adams, H. R (2009) Histamine, Serotonin and their Antagonists. In: Riviere J. E, Papich M. G, editors. Veterinary Pharmacology and Therapeutics, $9^{\text {th }}$ ed. Ames, Iowa: WileyBlackwell, pp.411-427.

[20] Purves D, Augustine G, Fitzpatrick D, Katz L, La Mantia A-S, Namara J. D, Williams S. M (2001) Neuroscience, $2^{\text {nd }}$ ed., I. Neural Signaling, 6. Neurotransmitters. Sunderland (MA): Sinaer Associates, Inc., pp. 275-296.

[21] Hirschowitz B. I (1979) H-2 histamine receptors. Annual Review of Pharmacology. 19: 203-244.

[22] Krstić M. K, Stepanović R. M,. Krstić S. K, Katušić Z. C (1989). Endothelium-dependent relaxation of the rat renal artery caused by activation of histamin $\mathrm{H}_{1}$-receptors. Pharmacology. 38: 113-120.

[23] [23]Levi R, Rubin L. E, Gross S. S (1991) Histamine in Cardiovascular Function and Dysfunction: Recent Developments. Effects of Histamine on the Vasculature. In: Uvnäs B, editor.Histamine and Histamine Antagonists, Vol. 97. Berlin: Springer - Verlag. pp. 354-367.

[24] Banks, R. O, Inscho E. W, Jacobson E. D (1984) Histamine H1 receptor antagonists inhibit autoregulation of renal blood flow in the dog. Circulation Research, 54: 248-252.

[25] Robinson C. P, Maxson S, (1982) Differences in histamine $\mathrm{H}_{1}$ and $\mathrm{H}_{2}$ receptor responses in several rabbit arteries. Res Commun Chemistry, Pathology and Pharmacology. 36: 355-366.

[26] Tayo F. M, Bevan J. A (1986). Pharmacological characterization of histamine receptors in the rabbit renal artery. European Journal of Pharmacology, 121: 129-133.

[27] Adams H. R (2009) Adrenergic agonists and antagonists. In: Riviere J. E, Papich M. G, editors. Veterinary Pharmacology and Therapeutics, $9^{\text {th }}$ ed. Ames, Iowa: WileyBlackwell, pp.125-155.

[28] Caccavelli L, Cussac D, Pellegrini I, Audinot V, Jaquet P, Enjalbert A (1992) D2 dopaminergic receptors: normal and abnormal transduction mechanisms. Horm Research. 38: 78-83.

[29] Adams H. R, Parker J. L (1979). Pharmacologic management of circulatory shock: cardiovascular drugs and corticosteroids. Journal of American Veterinary Medical Association. 175: 86-92.

[30] Goldberg L. I, Rajfer S. I (1985) Dopamine receptors: Application in clinical cardiology. Circulation, 72: 245-248.

[31] Murphy, M. B, Murray C, Shorten G. D (2001) Fenoldopam-A selective peripheral dopamine receptor agonist for the treatment of severe hypertension. N. Eng. J Med 345:1548-1557.

[32] Falck B, Nystedt T, Rosengren E, Stenflo J (1964) Dopamine and mast cells in ruminants. Acta Pharmacologica (Copenhagen). 21: 51-58.

[33] Sigrist N. E (2007) Use of dopamine in acute renal failure. J Vet Emerg Crit Care. 17: 117-126.

[34] Said, S. I, Mutt V (1970) Polypeptide with broad biological activity: isolation from small intestine. Science, 169: 1217-1218.

[35] Said, S. I (1988). This Week's Citation Classic. Current Contents, 20, 16 May, 16 (11416). 
[36] Cutz, E., Chan W, Track N. S, Goth A, Said S (1978). Release of vasoactive intestinal polypeptide in mast cells by histamine liberators. Nature 275: 661-662.

[37] Goetzl, E. J, Sreedharan S. P, Turck C. W (1988). Structurally distinctive vasoactive intestinal polypeptides from rat basophilic leukemia cells. Journal of Biology and Chemistry 263: 9083-9086.

[38] Ishikawa, S., Sperelakis N., 1987. A novel class $\left(\mathrm{H}_{3}\right)$ of histamine receptors on perivascular nerve terminals. Nature, 327: 158-160.

[39] Mori, T, Kawashima T, Beppu Y., Takagi K (1994). Histamine release induced by pituitary adenylate cyclase activating polypeptide from rat peritoneal mast cells. Arzneimittelforschung: 44: 1044-1046.

[40] Seebeck, J, M.Kruse, A. Schmidt-Choudhury, J. Schmidtmayer, W. E. Schmidt, 1998. Pituitary adenylate cyclase-activating polypeptide induces multiple signaling pathways in rat peritoneal mast cells. European Journal of Pharmacology, 352: 343-350.

[41] Champion, H, Bivalacqua T, Lambert D, Abassi R, Kadoitz P (1999) Analysis of vasoconstrictor responses to histamine in the hindlimb vascular bed of the rabbit. American Journal of Physiology, Regul. Intergr. Comp. Physiol. 277: R1179-R1187.

[42] Mirabella, N, Squillacioti C, Collitti M, Germano G, Pelagali A, Paino G (2002) Pituitary adenilate cyclase activating peptide (PACAP) immunoreactivity and mRNA expression in the duck gastrointestinal tract. Cell and Tissue Research 308: 347-359.

[43] Varty, L, Hey J (2002) Histamine H-3 receptor activation inhibits neurogenic sympathetic vasoconstriction in porcine nasal mucosa. European Journal of Pharmacology 452: 339-345.

[44] Squillacioti, C, Mirabella N, Colitti M, Esposito V, Paino G (2003) Expression and distribution of Pacap m-RNA in the duck gastrointestinal tract. Acta Veterinaria Brno 72 (Suppl. 7), S51.

[45] Yamada H, Kurokawa K (1994) Histochemical analysis of endothelin and its role in the central nervous system. In: H. Takahashi, editor. Central nervous system and blood pressure control. Yubunsha Publishing; Tokyo, pp. 105-114.

[46] Liu Y, Yamada H, Ochi J (1998) Immunocytochemical studies on endothelin in mast cells and macrophages in the gastrointestinal tract. Histochemistry and Cell Biology, 109: 301-307.

[47] Yamada H, Ochi J (1995). Histocytochemical and functional aspects on the "brainvascular peptides". Kaibogaku Zasshi, 70: 422-435.

[48] Yanagisawa M, Kurihara H, Kimura S, Tomobe Y, Kobayashi M, Mitsui Y, Yazaki Y, Goto K, Masaki T (1988): A novel potent vasoconstrictor peptide produced by vascular endothelial cells. Nature 332: 411-415.

[49] Miller, R.C, Pelton J.T, Huggins J.P (1993) Endothelins: From receptors to medicine. TIPS 14: $54-60$.

[50] Komuro I, Kurihara H, Sugiyama T, Yoshizumi M Takaku, F, Yazaki Y (1988) Endothelin stimulates c-fos and c-myc expression and proliferation of vascular smooth muscle cells. FEBS Letters, 238: 249-252.

[51] Tasaka, K, Kitazumi K (1994) The control of endothelin-1 secretion. Genetics and Pharmacology, 25: 1056-1069. 
[52] Sharifi, A, Schiffrin E (1999) Apoptosis in aorta of deoxycorticosterone acetate-salt hypertensive rats: effect of endothelin receptor antagonism. Journal of Hypertension, 15: 1441-1448.

[53] Schulz E, Ruschitzka F, Lueders S, Heydebluth R, Schrader J, Muller G.A (1995): Effects of endothelin on hemodynamics, prostaglandins, blood coagulation and renal function. Kidney International, 47: 795-801.

[54] Goto, K, Hama H, Kasuya Y (1996): Molecular pharmacology and pathophysiological significance of endothelin. Japanese Journal of Pharmacology 72: 261-290.

[55] Navar L. G, Incsho E. W,. Majid D. S. A, Imig J. D, Harison-Bernard L. M, Mitchel K. D (1996) Paracrine regulation of the renal microcirculation. Physiological Reviews 3: 425536.

[56] Kishi, F, Minami K, Okishima N, Murakami M, Mori S, Yano M, Niwa Y, Nakaya Y, H. Kido (1998) Novel 31-amino acid length endothelins cause contraction of vascular smooth muscle. Biochemical and Biophysical Research Communications 248: 387-390.

[57] Matsushima H, Yamada N, Matsue H. Shimada S (2004) The effects of endothelin-1 on degranulation, cytokine, and growth factor production by skin-derived mast cells. European Journal of Immunology 34: 1910-1919.

[58] Loesch A, Milner P, Burnstock G (1998) Endothelin in perivascular nerves. An electronimmunocytochemical study of rat basilar artery. Neuroreport 9: 3903-3906.

[59] Milner P, Loesch A, Burnstock G (2000) Neural endothelin in hypertension: immunoreactivity in ganglia and nerves to cerebral arteries of the spontaneously hypertensive rat. Journal of Vascular Research 37: 39-49.

[60] Loesch A, Burnstock G (2002) Endothelin in human cerebrovascular nerves. Clinical Science, 103: (Suppl. 48), 404S-407S.

[61] Mickey I, Kilford L, Kingbury A, Loesch A (2002) Endothelin in middle cerebral artery: A case of multiple system atrophy. The Histochemical Journal, 34: 469-477.

[62] Uchide T, Uchide T, Adur J, Yoshioka K, Sasaki T, Temma K, Saida K (2001) Endothelin1 in smooth muscle cells and mast cells of mouse uterus after parturition. Journal of Molecular Endocrinology 27: 165-173.

[63] Ozawa Y, Hasegawa T, Tsuchiya K, Yoshizumi M, Tamaki T (2003) Effect of endothelin1 (1-31) on the renal resistance vessels. The Journal of Medical Investigation, 50: 87-94.

[64] Yamamoto K (2000) Electron microscopy of mast cells in the venous wall of canine liver. Journal of Veterinary Medicine Science 62: 1183 - 1188.

[65] Bloom W, Fawsett D (1975) A Textbook of Histology., Philadelphia: W. B. Saunders Company. pp. 185-187.

[66] Stefanov I (2011). Morphofunctional aspects of dog's paranal sinus (Sinus paranalis). PhD Dissertation, Faculty of veterinary Medicine, Trakia University, Stara Zagora, pp. 104-152.

[67] Bredt D. S (2003) Nitric oxide signaling specifity - the heart of the problem. Journal of Cell Science 116: 9-15.

[68] Cauwels A, Janssen B, Buys E, Sips P, Brouckaert P (2006). Anaphylactic shock depends on PI3K and eNOS-derived NO. The Journal of Clinical Investigation, 116: 2244-2251. 
[69] Adams H. R (2009) Introduction to Neurohumoral transmission and the Autonomic Nervous System. In: Riviere J. E, Papich M. G, editors. Veterinary Pharmacology and Therapeutics, $9^{\text {th }}$ ed, Wiley-Blackwell, pp.101-123.

[70] Koranteng R. D, Dearman R. J, Kimber I, Coleman J. V (2000) Phenotyp variation in mast cell responsivenes to the inhibitory action of nitric oxide. Inflammation Research 49: 240-246.

[71] Swindle, E. J, Metcalfe D. D, Coleman J. W (2004) Rodent and human mast cells produce functionally significant intracellular reactive oxygen species but not nitric oxide. Journal of Biology and Chemisry 279: 48751-48759.

[72] Sekar Y, Moon T. C, Muñoz S, Befus A. D (2005) Role of nitric oxide in mast cells: controversies, current knowledge, and future applications. Immunologic Research 33: 223-240.

[73] Barret K, Pearce F (1991) Mast cells heterogeneity. In: Barret K, Pearce F, editors. Immunopharmacology of mast Cells and Basophils. London: Academic Press, pp. 29-38.

[74] Vollmerhaus, B., 1999: Harnorgane. In: Nickel R, Schummer A, Seiferle E, Lehrbuch der Anatomie der Hausteire, Bd. II, Einweide, $8^{\text {th }}$ ed. Berlin: Parey Buchervald, pp. 319-320.

[75] Fawcett D, Jensh R. P (2002) Mast cells, Smooth muscle. In: Bloom \& Fawcett's Concise Histology, $2^{\text {nd }}$ ed., London: Arnold, pp. 70-71, 113-115.

[76] Fasolato C, Hoth M, Matthews G, Penner R (1993) $\mathrm{Ca}^{2+}$ and $\mathrm{Mn}^{2+}$ influx through receptor - mediated activation of nonspecific cation channels in mast cells. Proceeding of the National Academy of Sciences of USA, 90: 3068-3072.

[77] Quin Y, McCloskey M (1993) Activation of mast cell $\mathrm{K}^{+}$channels through multiple G protein-linked receptors. Proceeding of the National Academy of Sciences of USA, 90: 7844-7888.

[78] Romanin C, Reinsprecht M, Pecht I, Schndler H (1991) Immunologically activated chloride channels involved in degranulation of rat mucosal mast cells. EMBO Journal, 10: 3603-3608.

[79] Dietrich J, Lindau M (1994) Chloride channels in mast cells: block by DIDS and role in exocytosis. Journal of General Physiology, 104: 1099-1111.

[80] Matsumoto Y, Inoue Y, Shimada T, Aikima T (2001) Brain mast cells act as an immune gate to the hypothalamic-pituitary-adrenal axis in dog. Journal of Experimental Medicine, 194: 71-78.

[81] Toyoda M, Makino T, Kagoura M, Horohachi M (2000) Immunological study of substance P in human skin mast cells. Archiv of Dermatology Research, 292: 418-421.

[82] Uchide, T, Uchide T, Adur J, Yoshioka K, Sasaki T, Temma K, Saida K (2001) Endothelin-1 in smooth muscle cells and mast cells of mouse uterus after parturition. Journal of Molecular Endocrinology, 27: 165-173. 